\title{
Thickness of Santa Fe Group sediments in the Española Basin south of Santa Fe, New Mexico, as estimated from aeromagnetic data
}

By Jeffrey D. Phillips and V.J.S. Grauch

U.S. Geological Survey, MS 964, Federal Center, Denver, CO 80225

Prepared in cooperation with the

NEW MEXICO OFFICE OF THE STATE ENGINEER

Open-File Report 2004-1354

\section{4}

Open-File Reports are used for the dissemination of information that must be released immediately to fill a public need or for information that is not sufficiently refined to warrant formal publication. As such, Open-File Reports should not be viewed as final reports of major scientific investigations. Because of their preliminary nature and possibility of being superseded, Open-File Reports do not introduce new or revised geologic, stratigraphic, hydrologic, or taxonomic nomenclature. In particular, Article 4(a) of the North American Stratigraphic Code excludes open-file releases for the naming or revising of formal geologic units.

U.S. Department of the Interior

U.S. Geological Survey 


\section{DISCLAIMERS}

\section{Thickness of Santa Fe Group sediments in the Española Basin south of Santa Fe, New Mexico, as estimated from aeromagnetic data}

Jeffrey D. Phillips and V. J. S. Grauch

Open-File Report 2004-1354

This publication and online data were prepared by an agency of the United States Government. Neither the United States Government nor any agency thereof nor any of their employees makes any warranty, expressed or implied, or assumes any legal liability or responsibility for the accuracy, completeness, or usefulness of any information, apparatus, product, or process disclosed in this report or represents that its use would not infringe privately owned rights. Reference therein to any specific commercial product, process, or service by trade name, trademark, manufacturer, or otherwise does not constitute or imply its endorsement, recommendation, or favoring by the United Sates Government or any agency thereof.

Although all online data have been used by the USGS, no warranty, expressed or implied, is made by the USGS as to the accuracy of the data and related materials and (or) the functioning of the software. The act of distribution shall not constitute any such warranty, and no responsibility is assumed by the USGS in the use of these data, software, or related materials.

The data contact is: Jeffrey D. Phillips

303-236-1206

jeff@usgs.gov

U. S. Geological Survey, MS 964

Box 25046, Denver Federal Center

Denver, CO 80225 USA 


\begin{abstract}
In the southern Española basin south of Santa Fe, New Mexico, weakly magnetic Santa Fe Group sediments of Oligocene to Pleistocene age, which represent the primary aquifers for the region, are locally underlain by moderately to strongly magnetic igneous and volcaniclastic rocks of Oligocene age. Where this relationship exists, the thickness of Santa Fe Group sediments, and thus the maximum thickness of the aquifers, can be estimated from quantitative analysis of high-resolution aeromagnetic data. These thickness estimates provide guidance for characterizing the ground-water resources in between scattered water wells in this area of rapid urban development and declining water supplies.
\end{abstract}

This report presents one such analysis based on the two-step extended Euler method for estimating depth to magnetic sources. The results show the general form of a north-trending synclinal basin located between the Cerrillos Hills and Eldorado with northward thickening of Santa Fe Group sediments. The increase in thickness is gradual from the erosional edge on the south to a U-shaped "Santa Fe embayment hinge line," north of which sediments thicken much more dramatically. Along the north-south basin axis, Santa Fe Group sediments thicken from 300 feet (91 meters) at the hinge line near latitude $35^{\circ} 32^{\prime} 30^{\prime \prime} \mathrm{N}$ to 2,000 feet (610 meters) at the Cerrillos Road interchange at Interstate 25 , north of latitude $35^{\circ} 36^{\prime} \mathrm{N}$. The depth analysis indicates that, superimposed on this general synclinal form, there are many local areas where the Santa Fe Group sediments may be thickened by a few hundred feet, presumably due to erosional relief on the underlying Oligocene volcanic and volcaniclastic rocks. Some larger areas of greater apparent thickening occur where the presence of magnetic rocks directly underlying the Santa Fe Group is uncertain. Where magnetic rocks are absent beneath the Santa Fe Group, the thickness cannot be estimated from the aeromagnetic data. 


\section{Introduction}

The occurrence of groundwater is of critical importance in the southern Española basin south of Santa Fe, New Mexico, between US 285 and the Cerrillos Hills and including Eldorado subdivision (Fig. 1), an area that is experiencing rapid urban growth and declining water supplies. A buried, mostly volcanic landform of Oligocene age (Grant, 1999) underlies the shallow Santa Fe Group aquifer in much of this area. Unfortunately, few wells exist over large portions of the region. Estimating the base of permeable sediments that overlie this less permeable volcanic surface helps characterize aquifer thickness, which will aid the administration of groundwater resources in this critical area.

Grauch and Bankey (2003) presented an extensive analysis of aeromagnetic data for the southern Española basin, including estimates of the thickness of Santa Fe Group sediments. Using a variety of magnetic interpretation techniques, they concluded that Santa Fe Group sediments in the area south of Santa Fe are generally less than $75 \mathrm{~m}(250 \mathrm{ft})$ thick, but locally fill deep pockets in the underlying Oligocene volcanic rocks up to $245 \mathrm{~m}(800 \mathrm{ft})$ thick. A primary goal of the present study is further definition of these pockets, and other variations in the Oligocene surface, using a newer and potentially more powerful magnetic depth analysis method.

Depth estimates to magnetic sources were computed in a rectangular study area that covers the southernmost extent of the Española basin and surrounding areas (Fig. 1). A subset of these depth estimates were considered to represent the thickness of Santa Fe Group sediments where we could reasonably expect that the sediments directly overlie Oligocene volcanic and volcaniclastic rocks. In some areas, this relationship is uncertain, as discussed below. For completeness, the uncertain estimates were included in a final representation of thickness of Santa Fe Group sediments. 


\section{Geologic Framework}

Within the study area (Fig. 1), the Santa Fe Group consists of the lower Pliocene to lower Pleistocene Ancha Formation, a primary aquifer, the Pliocene to lower(?) Pleistocene Tuerto Gravels, and the Miocene to upper Oligocene(?) Tesuque Formation, another aquifer (Lewis and West, 1995; Koning and others, 2002; Koning and Hallett, 2001). These weakly magnetic sediments are locally underlain by moderately to strongly magnetic rocks (Grauch and Bankey, 2003), consisting of Oligocene Cieneguilla basanite, Oligocene to lower Miocene(?) Espinaso Formation, and Oligocene intrusions in the Cerrillos Hills area (Kelley, 1978; Koning and Hallett, 2001; Fig. 1). The Ancha Formation is locally overlain by and interfingers with Pliocene basalts associated with the Cerros del Rio volcanic field (Sawyer and others, 2002; Fig. 1). In some areas the Oligocene igneous rocks are absent, and the Santa Fe Group is underlain by very weakly to weakly magnetic rocks of the Eocene Galisteo Formation (e.g., Koning and Hallett, 2001); where this occurs the thickness of the Santa Fe Group cannot be estimated from the aeromagnetic data.

The maximum thickness of the Ancha Formation is thought to increase from $20 \mathrm{~m}(60 \mathrm{ft})$ in the southeastern part of the area (Lisenbee, 1999) to $30 \mathrm{~m} \mathrm{(100} \mathrm{ft)} \mathrm{in} \mathrm{the} \mathrm{south} \mathrm{central} \mathrm{part} \mathrm{of} \mathrm{the} \mathrm{area}$ (Maynard and others, 2002) to $100 \mathrm{~m}$ (300 ft) in the central and northern parts of the area (Koning and

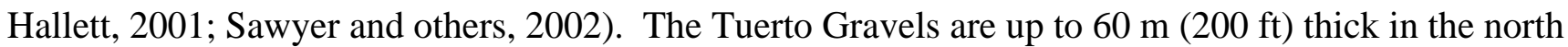
central part of the area (Koning and Hallett, 2001), and the Tesuque Formation forms a wedge up to an estimated $870 \mathrm{~m}(2850 \mathrm{ft})$ thick in the northern part of the area (Koning and Hallett, 2001). The maximum thickness of the underlying Espinaso Formation varies from $335 \mathrm{~m}(1100 \mathrm{ft})$ in the southeast (Lisenbee, 1999) to over $600 \mathrm{~m}(2000 \mathrm{ft})$ in the central and northern areas. In the northwest, the Espinaso is up to $420 \mathrm{~m}(1380 \mathrm{ft})$ thick, and is supplemented by up to $220 \mathrm{~m}(720 \mathrm{ft})$ of Cieneguilla basanite (Sawyer and others, 2002). Santa Fe Group sediments overlying Espinaso Formation were encountered in two deep wells, the Yates La Mesa Unit No. 3 in the center of the study area (YLM3, 
Table 1, Fig. 1, and Plate 5) and Yates La Mesa Unit No. 2 to the north of the study area (Fig. 1). About $4000 \mathrm{ft}$ (1220 m) of combined Ancha and Tesuque Formations overlying more than $2000 \mathrm{ft}$ (610 m) of Espinaso Formation are reported in the No. 2 well and $280 \mathrm{ft}(85 \mathrm{~m})$ of Ancha Formation overlying $2000 \mathrm{ft}$ (610 m) of Espinaso Formation are reported in the No. 3 well (Grant, 1999). However, identification of Santa Fe Group sediments is currently undergoing reevaluation in these and other wells (P. Johnson, New Mexico Bureau of Geology and Mineral Resources, written commun., 2003). In addition, the Oligocene volcanic rocks encountered in the No. 2 well may represent the Cieneguilla basanite rather than Espinaso Formation (G. Smith, University of New Mexico, oral commun., 2002).

It is clear that, in general, the thick Oligocene rocks permit considerable erosional relief on the base of the Santa Fe Group without much risk that these magnetic rocks will be absent at depth. Any depressions in the Oligocene erosion surface would have been filled by Santa Fe Group sediments shed from the Sangre de Cristo Mountains on the east and the Cerrillos Hills on the west (Koning and others, 2002). The Oligocene rocks do pinch out in the south and west of the study area due to folding, faulting, and intrusion.

\section{Aeromagnetic Data}

The high-resolution aeromagnetic data used in this study (Plate 1) were collected as part of the Sandoval-Santa Fe survey (USGS and others, 1999). The data were processed by removing flight-line noise, continued to a surface $100 \mathrm{~m}(328 \mathrm{ft})$ above the ground, merged with adjacent aeromagnetic surveys, and reduced to the magnetic pole as described by Sweeney and others (2002). The data are on a $50 \mathrm{~m}$ grid in a Universal Transverse Mercator projection based on the NAD27 horizontal datum. 


\section{The Two-Step Extended Euler Method}

The two-step extended Euler method for estimating magnetic source locations was described by Phillips (2002). It is basically a version of the 3-D Euler deconvolution method of Reid and others (1990) in which the homogeneity property of magnetic fields is used to solve for magnetic source locations from the values of the field and its first derivatives within small data windows. Input parameters include the size of the data window, the maximum depth of interest, the maximum percent error in the depth estimates, and the type of magnetic source being sought. The extended Euler method uses the two Hilbert transform components (Nabighian, 1984; Nabighian and Hansen, 2001) of the total field aeromagnetic data to supplement and stabilize solutions from the total field component. The new method has several advantages over conventional Euler deconvolution: (1) Many new solutions are generated from the Hilbert transform components that emphasize geologic trends difficult or impossible to pick up from analysis of the total field data alone. (2) By using combinations of the three components, up to seven solutions can be generated within each small data window; averaging the successful solutions produces a more consistent and reliable result. (3) The larger number and greater reliability of solutions permits direct gridding of the magnetic source horizon without extensive editing.

Typically the Euler method requires that the type of magnetic source (e.g., contact, thin sheet, line source, or point dipole) be specified by the interpreter prior to the analysis. In a study such as this one, a contact source is the appropriate choice. This is because the target Oligocene source rocks are generally thick compared to their depth of burial, and because choosing a contact source will give the shallowest possible depth solutions and thus the minimum thickness of the overlying Santa Fe Group sedimentary rocks. The magnetic source type is specified by a number, called the structural index, that is related to the dimensionality of the source. A point source, with three infinitesimal dimensions, has a structural index of three. A line source, with two infinitesimal, and one infinite dimension has a 
structural index of two. A sheet source, which has one infinitesimal dimension (its width or thickness), has a structural index of one. A contact, which has no finite dimensions, has a structural index of zero.

In the two-step Euler method, initial (contact) solutions that fall above a known minimum depth surface, and thus are not physically reasonable, can often be salvaged by moving them down to the minimum depth surface, and solving for a new magnetic source type. If the resulting magnetic source has a structural index between zero and three, it is a physically possible source on the minimum depth surface. If the index is greater than three, the actual source must lie above the minimum depth surface. In this way, the two-step method permits identification of magnetic sources that must lie above the specified minimum depth surface. Common geologic sources (contacts, dikes, and sills) have structural indices between zero and one, whereas cultural sources (pipelines, bridges, and buildings) have structural indices between two and three. By specifying a maximum structural index of one for solutions moved down to the minimum depth surface, we can separate sources that are clearly of geologic origin from sources that may be of cultural origin. In summary, sources that must lie above the surface are those having structural indices greater than three when moved down to the surface; sources that may lie above the surface are those having structural indices of between one and three when moved down to the surface.

Initially in this study we used the ground surface as the minimum depth surface, to allow the aquifer units to have zero thickness anywhere. This led to considerable relief on the Oligocene surface and disagreement with geologic cross sections and available well data in the Turquoise Hill quadrangle (Koning and Hallett, 2001). The disagreement was particularly severe in the northern part of the quadrangle where extensive cultural magnetic sources tended to mask the deep Oligocene surface. A better minimum depth surface was constructed from the well data, including some from the Seton Village quadrangle (Read and others, 1999; J.W. Hawley, written communication, 2000); newer well data in the Turquoise Hill, Seton Village, Galisteo, and Picture Rock quadrangles (P. Johnson, written 
communication, 2004); the available geologic cross sections; the mapped edge of the Santa Fe Group; and the southern geophysical profile model of Grauch and Bankey (2003) (Table 1). This new minimum depth surface (Plate 2) led to better agreement with the well data and the geologic cross sections, and it also allowed us to identify cultural magnetic sources in the northern part of the area, where the geologic sources are deep.

\section{Strategy}

The following strategy was used in constructing an estimated thickness grid for the Santa Fe Group:

(1) Construct a reasonable surface representing the minimum depth to the base of the Santa Fe Group by using existing geologic maps to determine the maximum lateral extent of the Santa Fe Group sedimentary rocks within the study area, and depths from available well data, geologic cross sections, and existing geophysical models (Plate 2).

(2) Estimate minimum magnetic source depths from the gridded aeromagnetic data using the twostep extended Euler method. Set the parameters so that most depth solutions of cultural origin are isolated and removed.

(3) Assign depth solutions falling outside the Santa Fe Group exposures to zero thickness values.

(4) Use existing geologic maps, well data, the aeromagnetic data, and the depth solutions to estimate the area where the Santa Fe Group sediments directly overlie magnetic rocks of Oligocene or older age. Non-zero depth solutions falling outside of this area will be discarded. 
(5) Grid the remaining depth solutions, mask areas where there is no valid depth information due to the absence of underlying magnetic rocks, and identify areas where the thickness solutions are suspect, based on lack of geologic control.

\section{Results}

\section{Minimum Depth Surface}

In order to test the accuracy of the gridding algorithm, the minimum depth surface constructed from the digitized Santa Fe Group contact and the point data in Table 1 was resampled at the point data locations. The resampled data (Sampled MDS, Table 1) agreed with the input data (Assumed Minimum Thickness, Table 1) to within ten percent for $94.7 \%$ of the points, and to within twenty percent for $97.7 \%$ of the points. This showed that the gridding algorithm introduces errors of less than twenty percent and generally less than ten percent in the resulting surfaces.

\section{Initial Depth Estimates}

Unedited results of the two-step extended Euler depth analysis are shown in Plate 3 , along with the polygon showing the geologically mapped extent of the contiguous Santa Fe Group. Non-contiguous Santa Fe Group exposures in the southwest corner of the area have been ignored in this study because they are not underlain by magnetic rocks. The gridded aeromagnetic data of Sweeney and others (2002) and computed Hilbert transform components were used to generate the Euler depth estimates. Parameters to the Euler program include a window size of $7 \times 7$ grid intervals $(350 \times 350 \mathrm{~m})$, a maximum depth of $3000 \mathrm{~m}$ below the ground, a maximum error in the depth estimates of 15 percent, an initial structural index of zero, and a maximum structural index of one. 


\section{Polygons}

Plate 4 shows the polygons used in the analysis. The polygon for the mapped extent of the Santa Fe Group (blue on Plate 4) was compiled from available geologic maps at a scale of 1:24000 or larger (Sawyer and others, 2002; Koning and Hallett, 2001; Read and others, 1999; Maynard and others, 2001, 2002; Lisenbee, 1999). Discontinuities at map boundaries were left in place.

The polygon for the area of magnetic rock units which directly underlie the Santa Fe Group (red on Plate 4) was compiled from the same geologic maps, along with limited well data, the aeromagnetic data, and the magnetic depth estimates. A detailed discussion follows which outlines, for each quadrangle (labeled on Plate 4), the various constraints used in defining this polygon.

In the southern Seton Village and northeastern Gallisteo quadrangles, a large gap between the Precambrian exposures of the Sangre de Cristo Mountains on the northeast and the last outcrop of Espinaso Formation on the southwest was bridged by following a sharp north-trending gradient in the gridded magnetic depth estimates that was close to the line drawn by Grauch and Bankey (2003). This gradient changes character at a point about $3.5 \mathrm{~km}$ from the mountain front, where there is a sudden increase in the estimated depths and a general loss of depth solutions to the north (Plate 3). We regard the area within $3.5 \mathrm{~km}$ of the mountain front and extending about $2.2 \mathrm{~km}$ to the northwest of this point to be an area where the Espinaso Formation may be absent beneath the Santa Fe Group (eastern gray area on Plate 4).

In the Gallisteo quadrangle, the red polygon approximately follows the mapped and predicted edge of the Espinaso Formation from Lisenbee (1999), however in some areas it appears from the aeromagnetic data that the lowest part of the Espinaso Formation is essentially nonmagnetic and therefore needed to be excluded from the polygon. 
In the Picture Rock quadrangle the red polygon follows the mapped extent of the Espinaso exposures from Maynard and others (2002). A narrow arm of the Santa Fe Group crosses this boundary, and the polygon was extended across this area using gradients in the gridded depth estimates. The configuration at the northern end of this extension (north of $35^{\circ} 27^{\prime} 30^{\prime \prime}$ latitude) has the greatest uncertainty. In the northwestern corner of this quadrangle the Espinaso Formation is thinned by folding and faulting, resulting in some window exposures of the underlying Galisteo Formation. In addition, the Oligocene and older rocks are extensively intruded by Oligocene igneous rocks of the Ortiz Porphyry Belt, some of which are magnetic. As a result it is very difficult to determine what rocks underlie the Santa Fe Group in this area, and whether or not they are magnetic (western gray area in Plate 4).

A similar lack of information exists in the northeast corner of the Madrid quadrangle (Maynard and others, 2001) and in the southeast corner of the Tetilla Peak quadrangle (Sawyer and others, 2002), where relations between the Espinaso Formation and the Santa Fe Group are unclear. It is likely that much of the Santa Fe Group in this area is underlain by some combination of magnetic and nonmagnetic Oligocene intrusive rocks; thinned, but possibly magnetic Espinaso Formation; non-magnetic Galisteo Formation; and interfingering basaltic lava flows of the Cerros del Rio volcanic field. Due to this uncertainty, we have chosen to include all of the Santa Fe Group exposures in this area within the polygon indicating underlying magnetic rocks (red in Plate 4), but to flag the area as uncertain (western gray area in Plate 4).

In the east central part of the Tetilla Peak quadrangle and the adjacent west central part of the Turquoise Hill quadrangle, there are some exposures of Cieneguilla basanite and the lower part of the Espinaso Formation adjacent to Santa Fe Group sedimentary rocks (Sawyer and others, 2002; Koning and Hallett, 2001). Based on the magnetic depth estimates, the basanite is clearly magnetic, but the 
Espinaso rocks are largely non-magnetic, except in very localized areas. In this area we have again chosen to include all of the Santa Fe Group exposures in this area within the polygon indicating underlying magnetic rocks, but to flag the area as uncertain.

Within the southwestern Turquoise Hill quadrangle, and possibly the north central Picture Rock quadrangle, there is an elongated window within the Espinaso Formation, where non-magnetic Galisteo Formation underlies the Santa Fe Group. This window is characterized geologically by Galisteo exposures in the north central Picture Rock quadrangle (Maynard and others, 2002) and in the west central Turquoise Hill quadrangle near La Cienega (Koning and Hallett, 2001), and by the John Gianardi No. 1 deep well in the south central Turquoise Hill quadrangle (JG1, Table 1, Fig.1, and Plate 5), which encountered Galisteo Formation directly under the Santa Fe Group, and a nearby water well to the north that encountered Espinaso Formation below the Santa Fe Group (Koning and Hallett, 2001). Geophysically the window is hard to define, due in part to the apparent non-magnetic character of the lower Espinaso Formation on the northeastern side of the window, and in part to the preponderance of magnetic Oligocene intrusive rocks on the southwestern side of the window. The eastern side of the window can be approximately defined along a fairly continuous gradient in the gridded magnetic depth estimates near the 100-foot depth contour (Plate 5). The estimated thickness of the Santa Fe Group is very uncertain to the west of this line.

\section{Masked Depth Estimates}

The polygons of Plate 4 were used to mask the depth estimates of Plate 3 in order to generate a grid of estimated thickness for the Santa Fe Group (Plates 5 and 6). Depth estimates from Plate 3 falling within the area of Santa Fe Group exposures (blue polygon) and within the area where magnetic rocks are thought to directly underlie the Santa Fe Group (red polygon) were left unchanged. Depth estimates within the area of Santa Fe Group exposures (blue polygon), but outside the area of 
underlying magnetic rocks (red polygon), were removed. Depth estimates outside of the area of Santa Fe Group exposures (blue polygon) were assigned to zero. These masked depth estimates were gridded to generate the Santa Fe Group thickness contours shown on Plate 5.

There are many small areas south of latitude $35^{\circ} 32^{\prime} 30^{\prime \prime}$ (Plate 5) where the Santa Fe Group appears to be thickened by a few hundred feet. These may be actual depressions in the underlying Oligocene surface due to erosion or they may indicate local zones where non-magnetic Oligocene rocks underlie the Santa Fe Group. Greater apparent thickening of over 500 feet is evident for two larger areas in the Seton Village quadrangle, and for many areas in the western part of the basin adjacent to the Cerrillos Hills and the Cerros del Rio volcanic field. With one exception in the Seton Village quadrangle, all of these apparent depressions occur in areas where the presence of magnetic rocks directly below the Santa Fe Group is uncertain (gray areas of Plate 4). North of the -1000 foot contour, there are many small localized areas of apparent thickening in the Santa Fe Group. Like the depressions to the south, these may be due to erosional channels in the top of the Espinosa Formation.

The estimated thickness grid can also be used to define a line where the Santa Fe Group begins to thicken rapidly to the north. We define this "Santa Fe embayment hinge line" to be the line where the regional dip of the base of the Santa Fe Group exceeds 100 feet per kilometer (Plate 6).

\section{Comparison of the Estimated Thickness Grid with the Point Data}

To test the results, the estimated thickness grid was resampled at the point data locations of Table 1. In areas where we were fairly certain that the Santa Fe Group was directly underlain by magnetic rocks, $65.6 \%$ of the resampled values (Estimated Thickness, Table 1) agreed with the point data to within ten percent or were otherwise consistent with the point data, and $81.2 \%$ agreed with the point data to within twenty percent or were otherwise consistent with the data. The thickness was overestimated by 
more than twenty percent in $14.9 \%$ of the cases and underestimated by more than twenty percent in $3.9 \%$ of the cases.

In areas where the presence of directly underlying magnetic rocks was considered uncertain (stippled areas, Plates 5 and 6 , over $91 \%$ of the resampled values overestimated the thickness by more than twenty percent. This confirms that the thickness estimates in these areas are unreliable.

At least two lines of evidence suggest that the tendency toward overestimation of thickness by the Euler method may be exaggerated in these comparisons. Early interpretations of the Yates La Mesa Unit No. 3 well (YLM3, Table 1, Fig. 1 and Plate 5) placed the Santa Fe Group thickness at 280 feet (Grant, 1999) or 250 feet (Koning and Hallett, 2001), which is much less than the 478 feet estimated from the aeromagnetic data. However, a recent reinterpretation (P. Johnson, written communication, 2004) places the thickness at 515 feet, which is within ten percent of the Euler thickness estimate. This suggests that reinterpretation of the well data can lead to better agreement with the Euler thickness estimates.

A well that was not used in defining the minimum depth surface, because it would have depressed the surface over a large area, is well W1 (Table 1, Plate 5). This well was drilled into a region of thickened Santa Fe Group identified by Grauch and Bankey (2003) and further defined by this report (Plates 5 and 6). The 649 foot thickness from the well (P. Johnson, written communication, 2004) is much greater than the Euler thickness estimate of 466 feet (Table 1), and both values are much greater than the interpolated minimum thickness value of 212 feet. This proves that there are thickened areas of the Santa Fe Group, and suggests that the Euler results may even underestimate the thickness in these areas. 


\section{Cultural and Shallow Geologic Magnetic Sources}

$\underline{\text { Plate } 7}$ characterizes the Euler depth solutions by structural index. Those having structural indices greater than three (red symbols on Plate 7) must lie above the minimum depth surface, and are probably due to localized cultural sources containing iron such as buildings and freeway overpasses. Those having structural indices between two and three (orange symbols on Plate 7) are probably due to cultural sources. Those having structural indices between zero and one (gray symbols on Plate 7) are likely due to shallow geologic sources such as dikes and sills. In much of the area, where the minimum depth surface is at or near the ground surface, cultural and shallow geologic sources cannot be separated using this approach. In these areas, the unmasked depth estimates (Plate 3) can be helpful in identifying shallow sources that may be of cultural origin. Some of the cultural magnetic sources seen on Plate 7 can be readily identified from USGS topographic maps as being due to large structures such as racetracks, airports, schools, prisons, and freeway interchanges.

\section{Conclusions}

In the southern Española basin south of Santa Fe, New Mexico, careful depth analysis of highresolution aeromagnetic data can be used to estimate the thickness of Santa Fe Group sediments, which represent the primary aquifers for the region. The estimates provide guidance for characterizing the ground-water resources in between scattered water wells in this area of rapid urban development and declining water supplies.

Results of the depth analysis (Plates 5 and $\underline{6}$ ) show the general form of a synclinal basin between the Cerrillos Hills and Eldorado with generally northward thickening of Santa Fe Group sediments, similar in form to previous estimates derived from aeromagnetic analysis (Grauch and Bankey, 2003) and from correlation of wells (Grant, 1999). The general form of the synclinal basin shows that Santa Fe 
Group sediments gradually thicken northward until they reach a U-shaped "Santa Fe embayment hinge line." North of the hinge line Santa Fe Group sediments thicken abruptly into the basin. Along the north-south axis of the basin, for example, the sediments thicken from zero on the south to 300 feet (91 meters) at the hinge line, near latitude $35^{\circ} 32^{\prime} 30^{\prime \prime}$, then dramatically thicken further north to reach 2000 feet (610 meters) at the Cerrillos Road interchange at Interstate 25, north of latitude $35^{\circ} 36^{\prime}$ (Plates 5 and 6). South of Gallina Arroyo (Fig. 1), the Santa Fe Group sediments are represented primarily by Ancha Formation, whereas generally north of the arroyo, the Santa Fe Group includes Tesuque Formation below 0-300 feet (0-91 meters) of Ancha Formation (Grant, 1999).

Superimposed on the general synclinal form, the depth analysis of this study indicates many small areas where Santa Fe Group sediments may increase in thickness by a few hundred feet, presumably due to erosional relief on the underlying Oligocene volcanic and volcaniclastic rocks. Some larger areas of greater apparent thickening occur where the presence of magnetic rocks directly underlying the Santa Fe Group is uncertain. Results in these areas should be regarded as unreliable. Where magnetic rocks are absent beneath the Santa Fe Group, the thickness cannot be estimated from the aeromagnetic data. Despite the uncertainties, this study has significantly improved the detailed information about local variations in thickness of Santa Fe Group sediments south of Santa Fe. 


\section{Digital Products}

The following digital files are provided with this report. All data are registered to a UTM, zone 13, map projection, using the NAD27 (Clark 1866) horizontal datum.

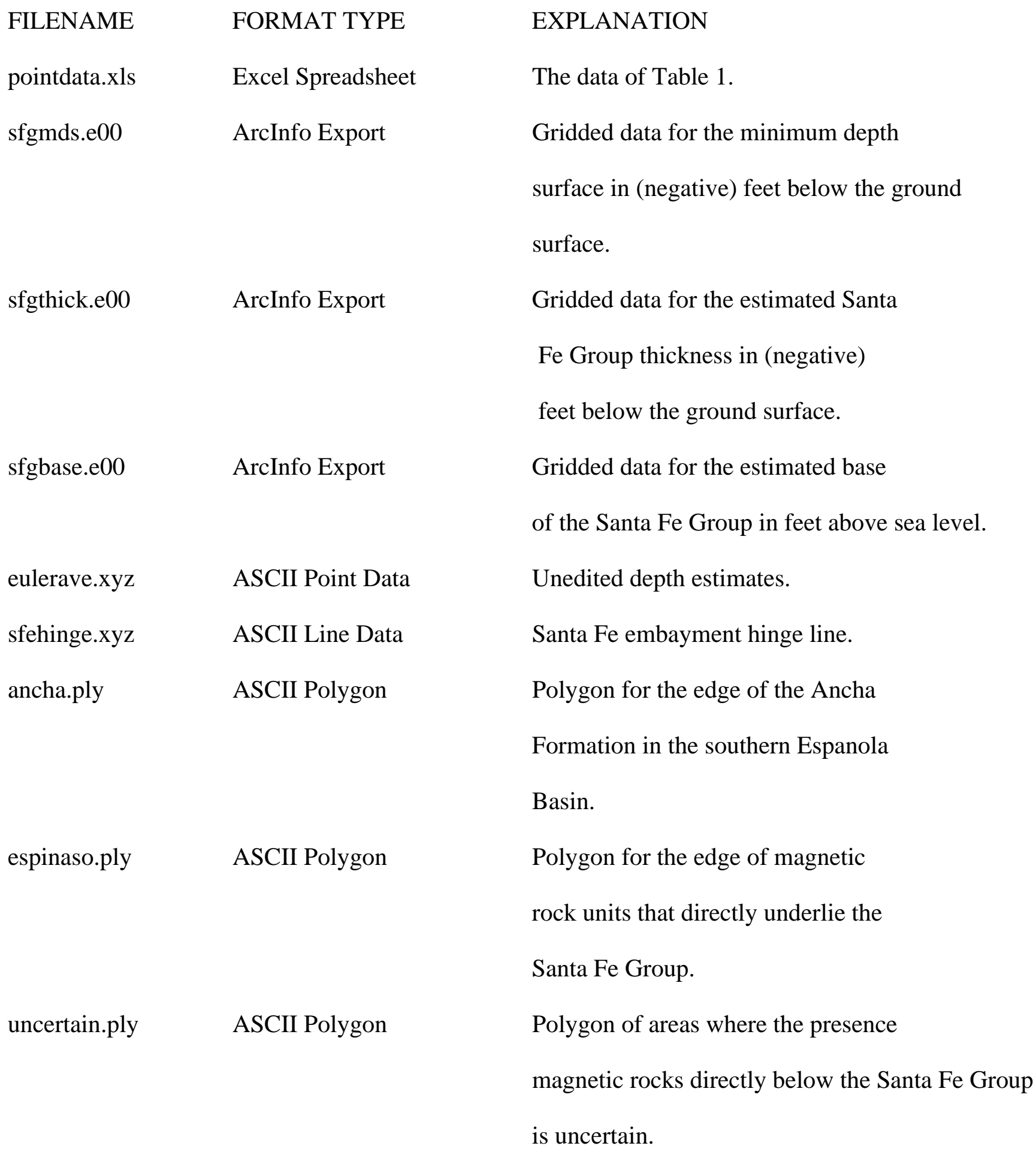




\section{References}

Grant, P.R., Jr., 1999, Subsurface geology and related hydrologic conditions, Santa Fe embayment and contiguous areas, New Mexico: New Mexico Geological Society Guidebook, 50th Field Conference, Albuquerque Geology, p. 425-435.

Grauch, V.J.S., and Bankey, Viki, 2003, Aeromagnetic interpretations for understanding the hydrogeologic framework of the southern Española basin, New Mexico: U.S. Geological Survey Open-File Report 03-124. [http://pubs.usgs.gov/of/2003/ofr-03-124/]

Kelley, V. C., 1978, Geology of Española basin, New Mexico: New Mexico Bureau of Mines and Mineral Resources Geologic Map 48, scale 1:125,000.

Koning, D.J., Connell, S.D., Pazzaglia, F.J., and McIntosh, W.C., 2002, Redefinition of the Ancha Formation and Pliocene-Pleistocene deposition in the Santa Fe embayment, north-central New Mexico: New Mexico Geology, v. 24, no. 3, p. 75-87.

Koning, D.J., and Hallett, R.B., 2001, Geologic map of the Turquoise Hill Quadrangle, Sante Fe County, New Mexico: New Mexico Bureau of Mines and Mineral Resources. [http://geoinfo.nmt.edu/publications/maps/ofgm/turquoise_hill/home.html]

Lewis, A.C., and West, F., 1995, Conceptual hydrologic systems for Santa Fe County: New Mexico Geological Society Guidebook, v. 46, p. 299-306. 
Lisenbee, A.L., 1999, Geology of the Galisteo 7.5' quadrangle, Santa Fe county, New Mexico: New Mexico Bureau of Mines and Mineral Resources, Open-File Report OF-DM 30. [http://geoinfo.nmt.edu/publications/maps/ofgm/galisteo/home.html]

Maynard, S.R., Lisenbee, A.L., and Rogers, John, 2002, Prelinimary geologic map of the Picture Rock 7.5-minute quadrangle, Sante Fe County, central New Mexico: New Mexico Bureau of Geology and Mineral Resources, Open-File Report DM-49. [http://geoinfo.nmt.edu/publications/maps/ofgm/picture rock/home.html]

Maynard, S.R., Sawyer, David, and Rogers, John, 2001, Preliminary geologic map of the Madrid 7.5minute quadrangle, Sante Fe and Sandoval Counties, central New Mexico: New Mexico Bureau of Mines and Mineral Resources, Open-File Report DM-40. [http://geoinfo.nmt.edu/publications/maps/ofgm/madrid/home.html]

Nabighian, M.N., 1984, Toward a three-dimensional automatic interpretation of potential field data via generalized Hilbert transforms: Fundamental relations: Geophysics, v.49, no.6, p.780-786.

Nabighian, M.N., and Hansen, R.O., 2001, Unification of Euler and Werner deconvolution in three dimensions via the generalized Hilbert transform: Geophysics, v.66, no.6, p.1805-1810.

Phillips, J.D., 2002, Two-step processing for 3D magnetic source locations and structural indices using extended Euler or analytic signal methods: Society of Exploration Geophysicists, 2002 Technical Program Expanded Abstracts, 4p. [http://seg.org/publications/archive/exAbsHist/abs pdf/2002/ea200207270730.pdf] 
Read, A.S., Rogers, J., Ralser, S., Ilg, B., and Kelly, S., 1999, Geology of the Seton Village 7.5-minute quadrangle, Sante Fe County, New Mexico: New Mexico Bureau of Mines and Mineral Resources, Open-File Geologic Map OG-GM 23, scale 1:12000.

Reid, A.B., Allsop, J.M., Granser, H., Millett, A.J., and Somerton, I.W., 1990, Magnetic interpretation in three dimensions using Euler deconvolution: Geophysics, v.55, no.1, p.80-91.

Sawyer, D.A., Shroba, R.R., Minor, S.A., Thompson, R.A., and Blossom, J.C., 2002, Geologic map of the Tetilla Peak quadrangle, Sante Fe and Sandoval Counties, New Mexico: U.S. Geological Survey Miscellaneous Field Studies Map MF-2352. [http://pubs.usgs.gov/mf/2002/mf-2352/]

Sweeney, R. E., Grauch, V. J. S., and Phillips, J. D., 2002, Merged digital aeromagnetic data for the Albuquerque and southern Española Basins, New Mexico: U. S. Geological Survey Open-File Report 02-205. [ http://pubs.usgs.gov/of/2002/ofr-02-0205]

U. S. Geological Survey, Sander Geophysics, Ltd., and Geoterrex, 1999, Digital data from the Sandoval-Santa Fe, Belen, and Cochiti aeromagnetic surveys, covering areas in Sandoval, Santa Fe, Rio Arriba, Valencia, and Socorro Counties, New Mexico: U. S. Geological Survey Open-File Report 99-404. 


\section{Figure and Plate Captions}

Figure 1. Location of the study area and area where thickness estimates could be made in the southern Española basin. Selected geographic features are also shown, such as cities and urban areas, main roads, and major drainages. Geologic contacts are from Kelly (1978).

Plate 1. Color-shaded relief image of reduced-to-pole aeromagnetic data on an observation surface

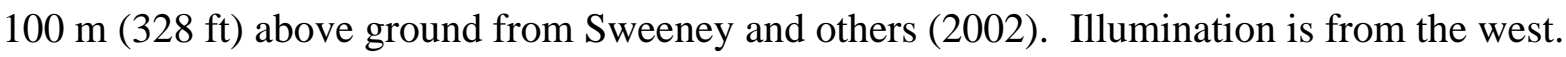
Note the nonlinear color scale. Grid interval is $50 \mathrm{~m}(164 \mathrm{ft})$.

Plate 2. Minimum depth surface used in the Euler analysis. This surface was constructed from the mapped Santa Fe Group contact, available well data, predicted thickness at wells from geologic cross sections, and a geophysical profile model. Depths are in feet below the ground surface.

Plate 3. Unedited two-step extended Euler depth estimates. The depth estimates, in feet below the ground surface, are on or below the minimum depth surface of Plate 2.

Plate 4. Polygons used in the analysis. Thickness estimates are possible for areas completely within the red, blue, and green polygons. Thickness estimates are very uncertain within the gray polygons.

Plate 5. Gridded and contoured Euler depth estimates representing thickness in feet of the Santa Fe Group in the southern Española basin. Estimates in stippled areas are uncertain. The variable contour interval is $50 \mathrm{ft}$ to $450 \mathrm{ft}, 100 \mathrm{ft}$ to $500 \mathrm{ft}$, and 500 and $1000 \mathrm{ft}$. Selected wells (JG1, YLM3, and W1) are also shown. 
Plate 6. Color-shaded relief image of gridded Euler depth estimates representing thickness in feet of the Santa Fe Group in the southern Española basin. Estimates in stippled areas are uncertain. Illumination is from the east.

Plate 7. Estimated non-zero structural index values for two-step Euler depth solutions. Structural indices greater than three indicate localized cultural magnetic sources. Structural indices between two and three indicate probable cultural magnetic sources. Structural indices between zero and one indicate probable geologic sources. Cultural and shallow geologic sources cannot be separated where the minimum depth surface is at or near the ground surface.

\section{Table Caption}

Table 1. Point data used in the analysis. Columns are defined as follows:

Site ID $=$ abbreviation for the well or site

UTM Easting NAD27 $(\mathrm{m})=$ Universal Transverse Mercator easting in meters, NAD27 horizontal datum.

UTM Northing NAD27 $(\mathrm{m})=$ Universal Transverse Mercator northing in meters, NAD27 horizontal datum.

Point Data for MDS (ft) = depths (feet below ground surface) used to define the minimum depth surface (MDS).

Reference for MDS = source for the point data value used. See Point Data References below.

Other Point Data $(\mathrm{ft})=$ other estimates of depth (feet below ground surface) at this location.

Other Refs. $=$ sources of other estimates of depth. See Point Data References below.

Resampled MDS = interpolated depth at the site from the minimum depth surface grid. This is a measure of the error introduced by gridding. Values within $10 \%$ of the point data are highlighted in green; values within $20 \%$ are highlighted in yellow; values greater than $20 \%$ are highlighted in orange; sites not used in defining the MDS are unhighlighted.

Gridding and Resampling Error = percent error in the resampled minimum depth surface. Color highlighting is as above.

Estimated Thickness $(\mathrm{ft})=$ estimated thickness of the Santa Fe Group at the site as interpolated from the results of the Euler depth analysis. Color highlighting as above indicates the level of agreement with the point data. Sites at which thickness could not be estimated are unhighlighted.

Disagreement with the Point Data $=$ percent error in the estimated thickness. Color highlighting is as above.

Comments $=$ notes on the thickness results at the site. 


\section{Point Data References}

1. Well data (P. Johnson, written communication, 2004)

2. Well data (J.W. Hawley, written communication, 2000)

3. Well data (Read and others, 1999)

4. Geologic cross sections (Koning and Hallet, 2001)

5. Wells on cross sections (Koning and Hallett, 2001)

6. Geophysical profile model (Grauch and Bankey, 20) 